\title{
SCATTERED SPECULATIONS ON THE QUESTION OF VALUE $^{1}$
}

\author{
GAYATRI CHAKRAVORTY SPIVAK
}

One of the determinations of the question of value is the predication of the subject. The modern "idealist" predication of the subject is consciousness. Labor-power is a "materialist" predication. Consciousness is not thought, but rather the subject's irreducible intendedness towards the object. Correspondingly, labor-power is not work (labor), but rather the irreducible possibility that the subject be more than adequate - super-adequate - to itself, labor-power: "it distinguishes itself [unterscheidet sich] from the ordinary crowd of commodities in that its use creates value, and a greater value than it costs itself" [Karl Marx, Capital, Vol. 1, 342; translation modified].

The "idealist" and the "materialist" are both exclusive predications. There have been attempts to question this exclusivist opposition, generally by way of a critique of the "idealist" predication of the subject: Nietzsche and Freud are the most spectacular European examples. Sometimes consciousness is analogized with labor-power as in the debates over intellectual and manual labor. Althusser's notion of "theoretical production" is the most controversial instance [For Marx 173-93]. The anti-Oedipal argument in France seems to assume a certain body without predication or without predication-function. (The celebrated "body without organs" is one product of this assumption - see Gilles Deleuze and Felix Guattari, Anti-Oedipus: Capitalism and Schizophrenia.) I have not yet been able to read this as anything but a last-ditch metaphysical longing. Since I remain bound by the conviction that subject-predication is methodologically necessary, I will not comment upon this anti-Oedipal gesture. The better part of my essay will concern itself with what the question of value becomes when determined by a "materialist" subject-predication such as Marx's. ${ }^{2}$ This is a theoretical enterprise requiring a certain level of generality whose particular political implications I have tabulated in passing and in conclusion. Here it is in my interest to treat the theory-politics opposition as if intact.

\footnotetext{
II am deeply grateful to Professor John Fekete for a thorough criticism of this piece.

${ }^{2}$ Any serious consideration of this question must take into account Georg Simmel's monumental Philosophy of Money (trans. Tom Bottomore and David Frisby, London: Routledge and Kegan Paul, 1978). My differences with Simmel are considerable. He writes in a brilliantly analogical vein that cannot acknowledge the discontinuity between "idealist" and "materialist" predications. Although he is technically aware of the argument from surplus-value, he is basically interested in value-in-exchange. His anti-socialism is thus directed against a pre-Marxian socialism. His few references to Marx, as the translators note in their admirable introduction, do not betray knowledge of the Marxian text. Yet I have also been deeply influenced by his meditations upon the relationship between money and individualism and upon the beginnings of what Volosinov later called "behavioral ideology"; in a certain way even by his cogitation upon woman as commodity. In these respects, he should be distinguished from both the Engels of the Origin of the Family and the Weber of The Protestant Ethic and the Spirit of Capitalism.
}

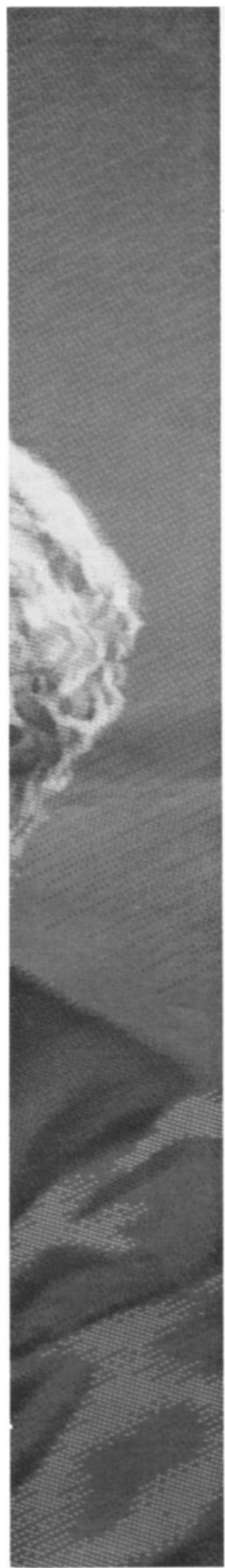


Before I embark on the generalized project, I will set forth a practical deconstructivistfeminist-Marxist position on the question of value in a narrow disciplinary context. The issue of value surfaces in literary criticism with reference to canon-formation. From this narrowed perspective, the first move is a counter-question: why a canon? What is the ethico-political agenda that operates a canon? By way of a critique of phallogocentrism, the deconstructive impulse attempts to decenter the desire for the canon. Charting the agenda of phallocentrism involves the feminist, that of logocentrism the Marxist interested in patterns of domination. Yet for a deconstructive critic it is a truism that a full undoing of the canon-apocrypha opposition, like the undoing of any opposition, is impossible. ("The impossibility of a full undoing" is the curious definitive predication of deconstruction.) When we feminist Marxists are ourselves moved by a desire for alternative canon-formations, we work with varieties of and variations upon the old standards. Here the critic's obligation seems to be a scrupulous declaration of "interest."

We cannot avoid a kind of historico-political standard that the "disinterested" academy dismisses as "pathos." That standard emerges, mired in overdeterminations, in answer to the kinds of counter-questions of which the following is an example: What subject-effects were systematically effaced and trained to efface themselves so that a canonic norm might emerge? Since, considered from this perspective, literary canon-formation is seen to work within a much broader network of successful epistemic violence, questions of this kind are asked not only by feminist and Marxist critics, but also by anti-imperialist deconstructivists. Such counter-questions and declarations are often seen as constituting the new Marxist (feminist-deconstructivist) point of view on literary value. Since I share the point of view they subtend, I place them on the threshold of my essay as I move into my more generalized (more abstract?) concerns.

The first distinction to make, then, is that the point of view above focuses on domination. Concentrating on the desire for the canon, on the complicity with old standards, and on epistemic violence, the practical perspective of the discipline in the narrow sense need do no more than persistently clean up (or muddy) the "idealist" field as it nourishes the question of value. Any consideration of the question of value in its "materialist" predication must, however, examine Marx's investigation of exploitation.

On the level of intellectual-historical gossip, the story of Marx's investigation of exploitation is well-known. Around 1857, Marx set out to unpack the concept-phenomenon money in response to the analyses and crisis-managerial suggestions of Frédéric Bastiat and Henry Charles Carey, and to the utopian socialist projects endorsed by Proudhon. It is our task to suggest that, by lifting the lid of that seemingly unified concept-phenomenon, Marx uncovered the economic text. Some times it seems that cooking is a better figure than weaving when one speaks of the text, although the latter has etymological sanction. Lifting the lid, Marx discovers that the pot of the economic is forever on the boil. What cooks (in all senses of this enigmatic expression) is Value. It is our task also to suggest that, however avant-gardist it may sound, in this uncovering Value is seen to escape the onto-phenomenological question. It is also our task to emphasize that this is not merely asking ourselves to attend once again to the embarrassment of the final economic determinant but that, if the subject has a "materialist" predication, the question of value necessarily receives a textualized answer. ${ }^{3}$

Let us first deal with the continuist version of Marx's scheme of value. ${ }^{4}$ Here is a crude

3 I am obliged here to admit that the "answer" that follows in this essay can in no way be considered definitive. This is my third attempt at working over these questions. The first, "Marx after Derrida," is to be found in William E. Cain, ed., Philosophical Approaches to Literature: New Essays on Nineteenth- and Twentieth-Century Texts (Lewisburg: Bucknell University Press, 1984). The second, an extended version of "the same piece," is forthcoming in Derek Attridge, et al., eds., Post-Structuralism and the Question of History (Cambridge: Cambridge University Press).

${ }^{4}$ If we think of Marx, Freud, Nietzsche (Derrida includes Heidegger) as the crucial Western thinkers of discontinuity, betrayed or obliged by their method to unbridgeable gaps and shifts in planes, a deconstructivist reading shows their texts to be a battleground between the intimations of discontinuity and the strong pull toward constructing a continuous argument with a secure beginning (arché), middle (historical enjambement), and end (telos). By and large, scholarship attempts to establish the continuity of the argument. It is therefore the continuist versions that are generally offered as the real Marx, the real Freud, the real Nietzsche. 
summary: use-value is in play when a human being produces and uses up the product (or uses up the unproduced) immediately. Exchange-value emerges when one thing is substituted for another. Before the emergence of the money-form, exchange-value is ad hoc. Surplus-value is created when some value is produced for nothing. Yet even in this continuist version value seems to escape the onto-phenomenological question: what is it ( $t i$ esti). The usual answer-value is the representation of objectified labor-begs the question of usevalue.

This continuist version is not absent in Marx, and certainly not absent in Engels. The intimations of discontinuity are most noticeably covered over in the move from the seven notebooks now collectively called the Grundrisse to the finished Capital I. It is a secondary revision of this version that yields the standard of measurement, indeed the calculus that emerges in the move from Capital I to Capital III. Vestiges of the "primary" continuist version linger in Derrida, whose version clearly animates Jean-Joseph Goux's Numismatiques, where most of the supporting evidence is taken from Capital I. Goux's reading, squaring the labor theory of value with the theories of ego-formation and signification in Freud and the early Lacan, is a rather special case of analogizing between consciousness and labor-power. Since my reading might seem superficially to resemble his, I will point at the unexamined presence of continuism in Goux in the next few paragraphs.

Goux's study seems ostensibly to issue from the French school of thought that respects discontinuities. Derrida gave Numismatiques his endorsement in "White Mythology," itself an important essay in the argument for discontinuity (see Margins of Philosophy 215 and passim). Goux takes the continuist version of the value-schema outlined above as given in Marx, though of course he elaborates upon it somewhat. Within that general continuist framework, then, Goux concentrates upon a unilinear version of the development of the money-form and draws an exact isomorphic analogy (he insists upon this) between it and the Freudian account of the emergence of genital sexuality. He concentrates next on Marx's perception that the commodity which becomes the universal equivalent must be excluded from the commodity function for that very reason. Here the analogy, again, resolutely isomorphic, is with Lacan's account of the emergence of the phallus as transcendental signifier. (For an early succinct account see Jacques Lacan, "The Signification of the Phallus.") Here is the claim: "It is the same genetic process, it is the same principle of discontinuous and progressive structuration which commands the accession to normative sovereignty of gold, the father and the phallus. The phallus is the universal equivalent of subjects; just as gold is the universal equivalent of products" [Goux 77; translation mine]. Goux's establishment of a relationship between Marx and Lacan in terms of gold and the phallus is based on his reading of exchange as mirroring and thus a reading of the origin of Value in the Lacanian "mirror-phase." Goux does notice that exchange value arises out of superfluity, but the question of use-value he leaves aside, perhaps even as an embarrassment.

Goux's argument is ingenious, but in the long run it seems to be an exercise in the domestication of Marx's analysis of Value. No doubt there are general morphological similarities between centralized sign-formations. But in order to see in those similarities the structural essence of the formations thus analogized, it is necessary to exclude the fields of force that make them heterogeneous, indeed discontinuous. It is to forget that Marx's critique of money is functionally different from Freud's attitude toward genitalism or Lacan's toward the phallus. It is to exclude those relationships between the ego/phallus and money that are attributive and supportive and not analogical. (Inheritance in the male line by way of patronymic legitimacy, indirectly sustaining the complex lines of class-formation, is, for example, an area where the case of the money-form, and that of the ego-form in the dialectic of the phallus, support each other and lend the subject the attributes of class- and genderidentity.) It is also to overlook the fact that Marx is a materialist dialectical thinker when he approaches the seemingly unified concept-phenomenon money. It is not the unilinear progressive account of the emergence of the money-form (Goux's model) that is Marx's main "discovery." It is in the full account of value-formation that the textuality of Marx's argument (rather than the recuperable continuist schema) and the place of use value is demonstrated, and the predication of the subject as labor-power (irreducible structural super-adequation the subject defined by its capacity to produce more than itself) shows its importance.

(To draw an adequate analogy between the emergence of the money-form and the 
Oedipal scenario is also to conserve the European Marx. It is in my political interest to join forces with those Marxists who would rescue Marxism from its European provenance. It is not surprising that in a later book Goux argues for a kinship between Marx and Freud in terms of their Jewish heritage. This argument may well be cogent, but it should not be seen as clinching the question of the historical differential in the geopolitical situation of Marxism and psychoanalysis.)

In comparison to these problems, the problem of winning Marx over to structuralist formalism would be a minor one, were it not that Anglo-U.S. continuist interests tend to lump together all attempts to read Marx in a structuralist way. The main enemy is here seen to be Althusser. Although I am critical of Althusser in many details of his argument, I would also pay tribute to a certain forgotten Althusser, precisely against the spirit of constructing phantom scapegoats, a personality-cultism in reverse. ${ }^{5}$ Derrida innocently contributes to this by putting Althusser and Goux together in "White Mythology." If one looks up nothing but the references given by Derrida to certain passages in Reading Capital, one sees immediately that Althusser's attempt, for better or for worse, is to read Marx's text through the straining logic of the metaphors in the Marxian text. Goux's continuist reading proceeds by way of certain slippages. I will draw my discussion of Goux to a close by citing only one: It seems unwise to suggest, as Goux does, that because exchange springs up within what is superfluous to a person's use, the exclusion of the universal symbol of value the moneymaterial) from the commodity function is therefore due to being-in-excess. By the Marxian argument, all value is in excess of use-value. But Value is not therefore excluded. The universal symbol measures this excess (or "deficit," as Goux correctly notes) and is excluded from the commodity function so that it does not, inconveniently, operate on two registers at once, both measuring and carrying Value. (The only limited analogy here is that the theory of the phallus must exclude its penis-function.) This is to collapse value, exchange-value, surplusvalue and money by way of an inflation of the concept of excess. In fact Goux, when he notices Marx's frequent metaphorizations of money as monarch, seems to elide the important differences between value-theory and theories of state formation.

In opening the lid of Money as a seemingly unitary phenomenon, Marx discovers a forever-seething chain in the pot: Value $\rightarrow$ Money $\rightarrow$ Capital. As in Hegel - of course Marx is not always a Hegelian but he seems to be here - those arrows are not irreversible. Logical schemes are not necessarily identical with chronological ones. But for purposes of philosophical cogitation and revolutionary agitation, the self-determination of the concept capital can be turned backward and forward and every which way. (Perhaps it was the relative ease of the former and the insurmountable difficulties of the latter that led Marx to question philosophical justice itself.) Keeping this in mind, let us flesh the seething chain with names of relationships:

\footnotetext{
${ }^{5}$ One of the chief complaints against Althusser is his privileging of "science" over "ideology," and his cutting up Marx into an earlier ideological and a later scientific thinker. I would submit that, in the spirit of a critique of positivism, Althusser [bricole-s or] tinkers with the name of science itself, re-constellates it by spinning it out [filer] as a convenient metaphor even as he establishes Marx's claim to be a scientist rather than merely a philosopher of history: "When I say that Marx organized a theoretical system of scientific concepts in the domain previously monopolized by philosophies of history, I am spinning out [filons] a metaphor which is no more than a metaphor." This allows him to chart out the two great continents of science: physics (nature) and mathematics (idea). Marx inaugurates a science of history (humankind) because he proposes rules by which the metaleptic semiosis of history as account might be deciphered. It is not seen by Althusser as an authoritative inductive leap: "Obviously this epistemological break is not exactly locatable [ponctuel] ... [it] inaugurates a history that will never come to an end." According to Althusser, Lenin consolidates this into a clear-cut program: "Lenin thus defines the ultimate essence of philosophical practice as an intervention in the theoretical domain. This intervention takes a double form: it is theoretical in its formulation of definite categories; and practical in the function of these categories." This is a "wild practice" ([pratique sauvage] on the analogy of "la psychanalyse sauvage" or pop psych). Althusser "generalizes this" into a (new) practice of philosophy, which recognizes that traditional philosophy is the arena of a denegation and a game played for the high stakes of scientificity. In this context, the terms "ideology" and "science," far from being a frozen and loaded binary opposition, are terms that must be thought over again and again (Lenin and Philosophy, trans. Ben Brewster [New York: Monthly Review Press, 1971], 38-40, 61, 66). The relationship between the theory of subject-formation in Lacanian psychoanalysis and the Althusserian critique of ideology, or between Freudian notions of overdetermination and Althusser's emendation of the theory of contradictions, is established by way of a developed argument, not, as in Goux, by an isomorphic analogy.
} 


\section{Value $\stackrel{\text { representation }}{\rightarrow}$ Money $\stackrel{\text { transformation }}{\rightarrow}$ Capital.}

(My account here is a rough summary of "The Chapter on Money," and section 1 of "The Chapter on Capital" in the Grundrisse.) This chain is "textual" in the general sense on at least two counts. ${ }^{6}$ The two ends are open, and the unified names of the relationships harbor discontinuities.

Exigencies of space will not permit elaboration of what is at any rate obvious - from the details of everyday life, through the practical mechanics of crisis-management, to the tough reasonableness of a book like Beyond the Waste Land (eds. Samuel Bowles et al.) - that the self-determination of capital as such is to date open-ended at the start. That moment is customarily sealed off in conventional Marxist political economic theory by extending the chain one step:

Labor $\stackrel{\text { representation }}{\rightarrow}$ Value $\stackrel{\text { representation }}{\rightarrow}$ Money $\stackrel{\text { transformation }}{\rightarrow}$ Capital. In fact, the basic premise of the recent critique of the labor theory of value is predicated on the assumption that, according to Marx, Value represents Labor. ${ }^{7}$

Yet the definition of Value in Marx establishes it as not only a representation but also a differential. What is represented or represents itself in the commodity-differential is Value: "In the exchange-relation of commodities their exchange-value appeared to us as totally independent of their use-value. But if we abstract their use-value from the product of labor, we obtain their value, as it has just been defined. The common element that represents itself (sich darstellt) in the exchange-relation of the exchange-value of the commodity, is thus value" [Capital / 128; translation modified]. Marx is writing, then, of a differential representing itself or being represented by an agency ("we") no more fixable than the empty and ad hoc place of the investigator or community of investigators (in the fields of economics, planning, business management). Only the continuist urge that I have already described can represent this differential as representing labor, even if "labor" is taken only to imply "as objectified in the commodity." It can be justly claimed that one passage in Capital I cannot be adduced to bear the burden of an entire argument. We must, however, remember that we are dealing here with the definitive passage on Value upon which Marx placed his imprimatur. For ease of argument and calculation, it is precisely the subtle openendedness at the origin of the economic chain or text seen in this passage that Marx must himself sometimes jettison; or, for perspectivizing the argument, must "transform." (For a consideration of the "transformation" problem in this sense, see Richard D. Wolff et al., "Marx's (Not Ricardo's) 'Transformation Problem': A Radical Conceptualization," History of Political Economy 14:4 [1982].)

I will presently go on to argue that the complexity of the notion of use-value also problematizes the origin of the chain of value. Let us now consider the discontinuities harbored by the unified terms that name the relationships between the individual semantemes on that chain. Such resident discontinuities also textualize the chain.

First, the relationship named "representation" between Value and Money. Critics like Goux or Marc Shell comment on the developmental narrative entailed by the emergence of the Money-form as the general representer of Value and establish an adequate analogy between this narrative on the one hand and narratives of psycho-sexuality or languageproduction on the other. (See Marc Shell, Money, Language, and Thought: Literary and

${ }^{6}$ Textual criticism of this sort assumes, a) in the narrow sense, that even "theoretical" texts are produced in language, and, b) that "reality" is a fabrication out of discontinuities and constitutive differences with "origins" and "ends" that are provisional and shifting. "One no longer has a tripartition between a field of reality, the world, a field of representation, the book, and a field of subjectivity, the author. But an arrangement [agencement] puts in connection certain multiplicities drawn in each of these orders, so much that a book does not have its continuation in the following book nor its object in the world, nor yet its subject in one or more authors" [Deleuze and Guattari, Mille plateaux 34; translation mine].

'I refer to this critique at greater length below. Here a brief checklist will suffice: Piero Sraffa, Production of Commodities by Means of Commodities (Cambridge: Cambridge. University Press, 1960); Samir Amin, The Law of Value and Historical Materialism (New York: Monthly Review Press, 1978); Diane Elson, ed., Value: The Representation of Labor in Capitalism (Atlantic Highlands, N...: Humanities Press, 1979); Ian Steedman, Marx After Sraffa (London: Verso Edition, 1981); lan Steedman, et al., The Value Controversy (London: Verso Edition, 1981). 
Philosophical Economies From the Medieval to the Modern Era. It should be remarked that Shell's narrative account of the history of money is less subtle than Marx's analysis of it.) My focus is on Marx's effort to open up the seemingly unified phenomenon of Money through the radical methodology of the dialectic-opening up, in other words, the seemingly positive phenomenon of money through the work of the negative. At each moment of the three-part perspective, Marx seems to indicate the possibility of an indeterminacy rather than stop at a contradiction, which is the articulative driving force of the dialectical morphology. Here is the schema, distilled from the Grundrisse:

Position: The money commodity - the precious metal as medium of universal exchange - is posited through a process of separation from its own being as a commodity exchangeable for itself: "From the outset they represent superfluity, the form in which wealth originally appears [ursprünglich erscheint]" [Grundrisse 166; translation modified]. As it facilitates commodity exchange "the simple fact that the commodity exists doubly, in one aspect as a specific product whose natural form of existence ideally contains (latently contains) its exchange value, and in the other aspect as manifest exchange value (money), in which all connection with the natural form of the product is stripped away again - this double, differentiated existence must develop into a difference" [147]. When the traffic of exchange is in labor-power as commodity, the model leads not only to difference but to indifference: "In the developed system of exchange ... the ties of personal dependence, of distinctions, of education, etc. are in fact exploded, ripped up . . . ; and individuals seem independent (this is an independence which is at bottom merely an illusion, and it is more correctly called indifference [Gleichg ültgkeit - im Sinne der Indifferenz - Marx emphasizes the philosophical quality of indifference]" [163].

Negation: Within circulation seen as a constantly repeated circle or totality, money is a vanishing moment facilitating the exchange of two commodities. Here its independent positing is seen as "a negative relation to circulation," for, "cut off from all relation to [circulation], it would not be money, but merely a simple natural object" [217]. In this moment of appearance its positive identity is negated in a more subtle way as well: "If a fake $£$ were to circulate in the place of a real one, it would render absolutely the same service in circulation as a whole as if it were genuine" [210]. In philosophical language: the self-adequation of the idea, itself contingent upon a negative relationship, here between the idea of money and circulation as totality, works in the service of a functional in-adequation (fake $=$ real).

Negation of negation: Realization, where the actual quantity of money matters and capital accumulation starts. Yet here too the substantive specificity is contradicted (as it is not in unproductive hoarding). For, "to dissolve the things accumulated in individual gratifications is to realize them" [234]. In other words, logical progression to accumulation can only be operated by its own rupture, releasing the commodity from the circuit of capital production into consumption in a simulacrum of use-value.

I am suggesting that Marx indicates the possibility of an indeterminacy rather than only a contradiction at each of these three moments constitutive of the chain

$$
\text { Value } \stackrel{\text { representation }}{\rightarrow} \text { Money } \stackrel{\text { transtormation }}{\rightarrow} \text { Capital. }
$$

This textualization can be summarized as follows: the utopian socialists seemed to be working on the assumption that money is the root of all evil: a positive origin. Marx applies the dialectic to this root and breaks it up through the work of the negative. At each step of the dialectic something seems to lead off into the openendedness of textuality: indifference, inadequation, rupture. (Here Derrida's implied critique of the dialectic as organized by the movement of semantemes and by the strategic exclusion of syncategoremes ["White Mythology" 270] would support the conduct of Marx's text.)

Let us move next to the relationship named "transformation between Money and Capital," a relationship already broached in the previous link. (This is not identical with the "transformation problem" in economics.) An important locus of discontinuity here is the socalled primitive or originary accumulation. Marx's own account emphasizes the discontinuity in comical terms, and then resolves it by invoking a process rather than an origin: 
We have seen how money is transformed into capital; how surplus-value is made through capital, and how more capital is made from surplus-value. But the accumulation of capital presupposes surplus-value; surplus-value presupposes capitalist production; capitalist production presupposes the availability of considerable masses of capital and labor-power in the hands of commodity producers. The whole movement, therefore, seems to turn around in a never-ending circle, which we can only get out of by assuming a "primitive" [ursprünglich: originary] accumulation ... which precedes capitalist accumulation; an accumulation which is not the result of the capitalist mode of production but its point of departure. This primitive accumulation plays approximately the same role in political economy as original sin does in theology. Adam bit the apple, and thereupon sin fell on the human race. [Capital / 873]

Marx's resolution:

The capital-relation presupposes a complete separation between the workers and the ownership of the conditions for the realization of their labor. . . . So-called primitive accumulation, therefore, is nothing else than the historical process of divorcing the producer from the means of production. [Capital I 874-75]

This method of displacing questions of origin into questions of process is part of Marx's general Hegelian heritage, as witness his early treatment, in the Economic and Philosophical Manuscripts, of the question: "Who begot the first man, and nature in general?" [Early Writings 357].

When, however, capital is fully developed - the structural moment when the process of extraction, appropriation, and realization of surplus-value begins to operate with no extraeconomic coercions - capital logic emerges to give birth to capital as such. This moment does not arise either with the coercive extraction of surplus-value in pre-capitalist modes of production, or with the accumulation of interest capital or merchant's capital (accumulation out of buying cheap and selling dear). The moment, as Marx emphasizes, entails the historical possibility of the definitive predication of the subject as labor-power. Indeed, it is possible to suggest that the "freeing" of labor-power may be a description of the social possibility of this predication. Here the subject is predicated as structurally super-adequate to itself, definitively productive of surplus-labor over necessary labor. And because it is this necessary possibility of the subject's definitive super-adequation that is the origin of capital as such, Marx makes the extraordinary suggestion that Capital consumes the use-value of laborpower. If the critique of political economy were simply a question of restoring a society of use-value, this would be an aporetic moment. "Scientific socialism" contrasts itself to a "utopian socialism" committed to such a restoration by presupposing labor outside of capital logic or wage-labor. The radical heterogeneity entailed in that presupposition was dealt with only very generally by Marx from the early Economic and Philosophical Manuscripts onwards. Indeed, it may perhaps be said that, in revolutionary practice, the "interest" in social justice "unreasonably" introduces the force of illogic into the good use-value fit - philosophical justice - between Capital and Free Labor. If pursued to its logical consequence, revolutionary practice must be persistent because it can carry no theoretico-teleological justification. It is perhaps not altogether fanciful to call this situation of open-endedness an insertion into textuality. The more prudent notion of associated labor in maximized social productivity working according to "those foundations of the forms that are common to all social modes of production" is an alternative that restricts the force of such an insertion [Capital III 1016].

In the continuist romantic anti-capitalist version, it is precisely the place of use-value (and simple exchange or barter based on use-value) that seems to offer the most secure anchor of social "value" in a vague way, even as academic economics reduces use-value to mere physical co-efficients. This place can happily accommodate word-processors (of which more later) as well as independent commodity production (hand-sewn leather sandals), our students' complaint that they read literature for pleasure not interpretation, as well as most of 
our "creative" colleagues' amused contempt for criticism beyond the review, and mainstream critics' hostility to "theory." In my reading, on the other hand, it is use-value that puts the entire textual chain of Value into question and thus allows us a glimpse of the possibility that even textualization (which is already an advance upon the control implicit in linguistic or semiotic reductionism) may be no more than a way of holding randomness at bay.

For use-value, in the classic way of deconstructive levers, is both outside and inside the system of value-determinations (for a discussion of deconstructive "levers," see Derrida, Positions 71). It is outside because it cannot be measured by the labor theory of value - it is outside of the circuit of exchange: "A thing can be a use-value without being a value" [Capital I 131]. It is, however, not altogether outside the circuit of exchange. Exchange-value, which in some respects is the species-term of Value, is also a superfluity or a parasite of use-value: "This character (of exchange) does not yet dominate production as a whole, but concerns only its superfluity and is hence itself more or less superfluous . . . an accidental enlargement of the sphere of satisfactions, enjoyments. . . It therefore takes place only at a few points (originally at the borders of the natural communities, in their contact with strangers" [Grundrisse 204].

The part-whole relationship is here turned inside out. (Derrida calls this "invagination." See "The Law of Genre," Glyph 7 [1980]. My discussion of "invagination is to be found in Displacement: Derrida and After, ed. Mark Krupnick 186-89.) The parasitic part (exchangevalue) is also the species term of the whole, thus allowing use-value the normative inside place of the host as well as banishing it as that which must be subtracted so that Value can be defined. Further, since one case of use-value can be that of the worker wishing to consume the (affect of the) work itself, that necessary possibility renders indeterminate the "materialist" predication of the subject as labor-power or super-adequation as calibrated and organized by the logic of capital. In terms of that necessarily possible "special case," this predication can no longer be seen as the excess of surplus labor over socially necessary labor. The question of affectively necessary labor brings in the attendant question of desire and thus questions in yet another way the mere philosophical justice of capital logic without necessarily shifting into utopian idealism.

If a view of affectively necessary labor (as possible within the present state of socialized consumer capitalism) as labor as such is proposed without careful attention to the international division of labor, its fate may be a mere political avant-gardism. This, in spite of its sincere evocations of the world economic system, is, I believe, a possible problem with Antonio Negri's theory of zerowork. ${ }^{8}$ The resistance of the syncategoremes strategically excluded from the system so that the great semantemes can control its morphology (Derrida) can perhaps be related to the heterogeneity of use-value as a private grammar. For Derrida, however, capital is generally interest-bearing commercial capital. Hence surplus-value for him is the super-adequation of capital rather than a "materialist" predication of the subject as super-adequate to itself. This restricted notion can only lead to "idealist" analogies between capital and subject, or commodity and subject.

The concept of socially necessary labor is based on an identification of subsistence and reproduction. Necessary labor is the amount of labor required by the worker to "reproduce" himself in order to remain optimally useful for capital in terms of the current price-structure. Now if the dynamics of birth-growth-family-life reproduction is given as much attention as, let us say, the relationship between fixed and variable capitals in their several moments, the "materialist" predication of the subject as labor-power is rendered indeterminate in another way, without therefore being "refuted" by varieties of utopianism and "idealism." This expansion of the textuality of value has often gone unrecognized by feminists as well as mainstream Marxists, when they are caught within hegemonic positivism or orthodox dialec-

\footnotetext{
${ }^{8}$ For excellent elaborations of this theory, see the "Introduction"-s and indeed the entire issues of Zerowork: Political Materials 1 \& 2 (December 1975 and Fall 1977). One of the most revolutionary suggestions of this thought is that the working class includes the unwaged as well as the waged. I am suggesting that the unwaged under socialized capital has a different status and definition from the unwaged in the peripheral capitalisms.
} 
tics. ${ }^{9}$ They have sometimes tried to close off the expansion, by considering it as an opposition (between Marxism and feminism), or by way of inscribing, in a continuist spirit, the socializing or ideology-forming functions of the family as direct means of producing the worker and thus involved in the circuit of the production of surplus-value for the capitalist. They have also attempted to legitimize domestic labor within capital logic. Most of these positions arise from situational exigencies. My own involvement with them does not permit critical distance, as witness in the last page of this essay. That these closing off gestures are situationally admirable is evident from the practical difficulty of offering alternatives to them.

Let us consider the final item in the demonstration of the "textuality" of the chain of value. We have remarked that in circulation as totality, or the moment of negation in Marx's reading of money, money is seen as in a negative relation to circulation because, "cut off from all relation to (circulation) it would not be money, but merely a simple natural object."

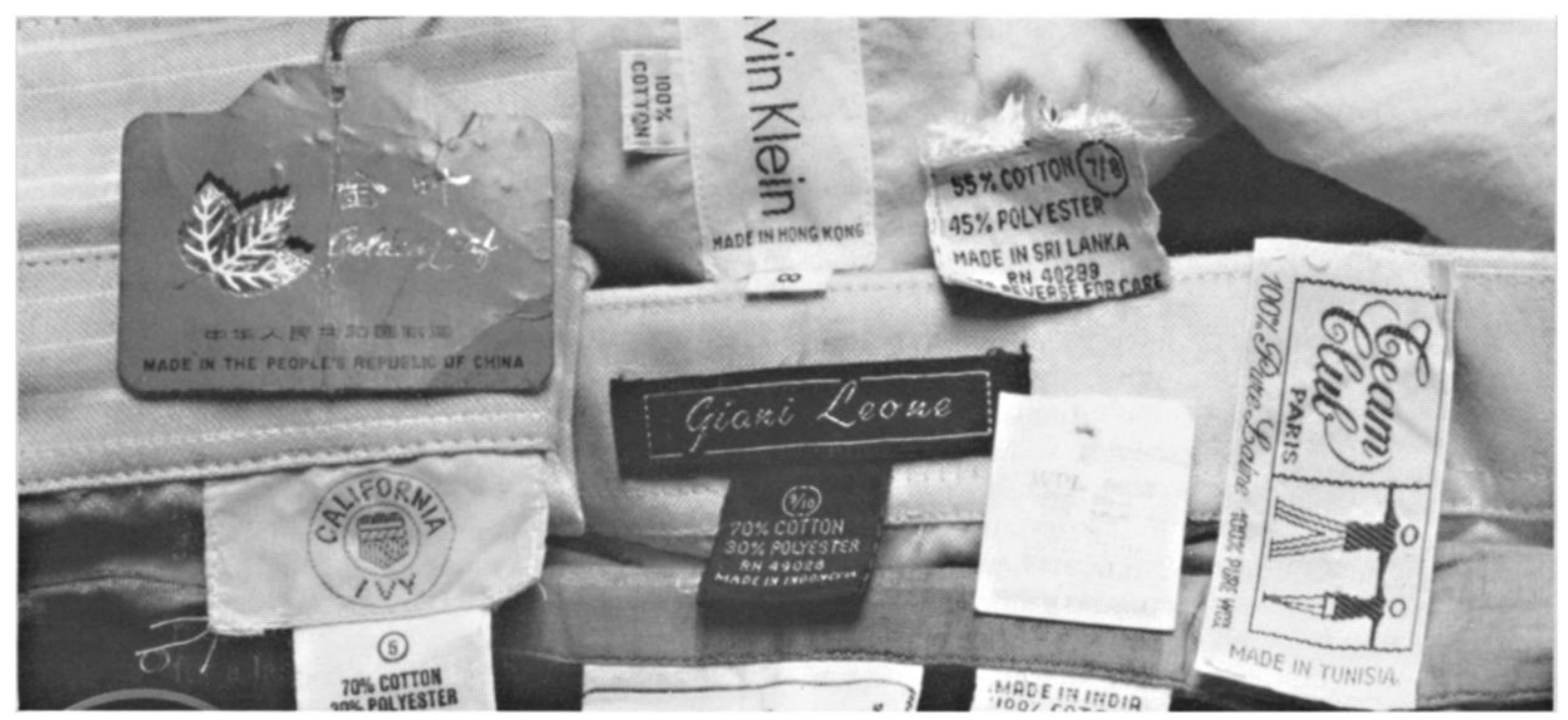

Circulation as such has the morphological (if not the "actual") power to insert Money back into Nature, and to banish it from the textuality of Value. Yet it is also circulation that bestows textuality upon the Money-form. Textuality as a structural description indicates the work of differentiation (both plus and minus) that opens up identity-as-adequation. Circulation in the following passage does precisely that with the restricted circuit of adequation within the money-form itself: "You may turn and toss an ounce of gold in any way you like, and it will never weigh ten ounces. But here in the process of circulation one ounce practically does weigh ten ounces." Marx describes this phenomenon as the "Dasein" of the coin as "value sign" [Wertzeichen]. "The circulation of money is an outer movement [auBere Bewegung]. . . . In the friction with all kinds of hands, pouches, pockets, purses ... the coin rubs off. ... By being used it gets used up" [A Contribution to the Critique of Political Economy 108; the translation of "Dasein" as "the work it performs" seems puzzling].

If in its first dialectical "moment," circulation has the morphological potential of canceling Money back into Nature, in its third "moment" it is shown to run the risk of being itself

"One striking exception is Diane Elson, "The Value Theory of Labour," in Elson, ed., Value. I propose something similar in "Feminism and Critical Theory," forthcoming in For Alma Mater, Paula Treichler (Urbana: University of Illinois Press). 
sublated into Mind: "The continuity of production presupposes that circulation time has been sublated [aufgehoben]. The nature of capital presupposes that it travels through the different phases of circulation not as it does in the idea-representation [Vorstellung] where one concept turns into the other at the speed of thought [mit Gedankenschnelle], in no time, but rather as situations which are separated in terms of time" [Grundrisse 548; translation modified]. By thus sublating circulation into Mind, production (of Value) as continuous totality would annul Value itself. For Value would not be value if it were not realized in consumption, strictly speaking, outside of the circuit of production. Thus capital, as the most advanced articulation of value "presupposes that it travels through different phases." The scheme is made problematic by the invagination of use-value, as discussed earlier in this essay.

Has circulation time of capital been sublated into the speed of Mind (and more) within telecommunication? Has (the labor theory of) Value become obsolete in micro-electronic capitalism? Let us mark these tantalizing questions here. I shall consider them at greater length below.

The consideration of the textuality of Value in Marx, predicated upon the subject as labor-power, does not answer the onto-phenomenological question "What is Value?," although it gives us a sense of the complexity of the mechanics of evaluation and valueformation. It shows us that the Value-form in the general sense and in the narrow - the economic sphere as commonly understood being the latter - are irreducibly complicitous. It implies the vanity of dismissing considerations of the economic as "reductionism." I have already indicated various proposed formulations that have the effect of neutralizing these suggestions: to find in the development of the money-form an adequate analogy to the psychoanalytic narrative; to see in it an analogy to metaphor or language; to subsume domestic or intellectual labor into a notion of the production of value expanded within capital logic. What narratives of value-formation emerge when consciousness itself is subsumed under the "materialist" predication of the subject?

If consciousness within the "idealist" analogy is seen as necessarily superadequate to itself by way of intentionality, we can chart the emergence of ad hoc universal equivalents that measure the production of value in what we may loosely call "thought." Like the banishment of the money-commodity from the commodity-function, these equivalents can no longer themselves be treated as "natural examples." (Because these analogies are necessarily loose, one cannot be more specific in that last phrase.) One case of such a universal equivalent is "universal humanity" - both psychological and social - as the touchstone of value in literature and society. It is only half in jest that one would propose that the "credit" of certain "major" literatures is represented by capital-accumulation in terms of the various transformations of this universal equivalent. "Pure theory," within the Althusserian model of "theoretical production," may be seen as another case of a universal equivalent. The relativization of Value as a regression into the narrative stage where any commodity could be "cathected" as the value-form is, to follow Goux's analogy, the Freudian stage of polymorphous perversion, and can be channeled into aesthetics as varied as those of symbolism and post-modernism.

I have already commented on Goux's gloss on the Freudo-Lacanian narrative of the emergence of the phallus-in-the-genital stage as the universal equivalent of value. Nietzsche in The Genealogy of Morals gives us two moments of the separation and transformation of an item from within the common circuit of exchange. They are worth mentioning because The Genealogy of Morals is Nietzsche's systematic attempt at a "critique of moral values," a "put[ting] in question [in Frage stellen]" of "the value of these values" [Grundrisse 348; translation modified]. The Nietzschean enterprise is not worked out on what I call a "materialist" subject-predication as labor-power, but rather by way of a critique of the "idealist" subjectpredication as consciousness, through the double determinants of "philology" and "physiology" [Nietzsche, On the Genealogy of Morals and Ecce Homo 20]. Because it is a reinscription of the history of value as obliterated and discontinuous semiotic chains - ongoing sign-chains - disconnected references to money (guilt and punishment as systems of exchange), and to the inscription of coins, abound. The more crucial moment, the separation of the money-commodity, is touched upon once at the "beginning" and once at the inauguration of the "present," as the separation of the scapegoat and the sublation of that 
gesture into mercy respectively. That sublation is notoriously the moment of the creditor sacrificing himself for the debtor in the role of God's son in the Christ story [On the Genealogy of Morals and Ecce Homo 77, 72]. (Any notions of "beginning" and "present" in Nietzsche are made problematic by the great warning against a successful genealogical method: "All concepts in which an entire process is semiotically concentrated elude definition; only that which has no history is definable" [ibid. 80].)

I think there can be no doubt that it is this separation rather than inscription or coining that is for Marx the philosophically determining moment in the discourse of value. Attention to Marx's concept-metaphor of the foreign language is interesting here. Often in our discussion of language the word seems to retain a capital " $\mathrm{L}$ " even when it is spelled in the lower case or re-written as parole. Using a necessarily pre-critical notion of language, which suggests that in the mother-tongue "word" is inseparable from "reality," Marx makes the highly sophisticated suggestion that the development of the value-form separates "word" and "reality" (signifier and signified), a phenomenon that may be appreciated only in the learning of a foreign language: "To compare money with language is . . erroneous. . . Ideas which have first to be translated out of their mother tongue into a foreign language in order to circulate, in order to become exchangeable, offer a somewhat better analogy; but the analogy then lies not in language, but in the foreignness of language" [Crundrisse 163. If this were a technical discussion where it was necessary to respect the specificity of the vocabulary of linguistics, I would not of course, equate word/reality and signifier/signified.] It is certainly of interest that, using a necessarily post-monetary notion of Value-in-exchange, which must suggest that "political economy [is] . . . concerned with a system of equivalence [système d'équivalence] . . . [between a specific] labor and [a specific] wage [un travail et un salaire]," Saussure shows us that, even in the mother tongue, it is the work of difference that remains originary, that even as it is most "native," language is always already "foreign," that even in its "incorporeal essence," "the linguistic signifier... [is] constituted not by its material substance but only [uniquement] by the differences that separate its acoustic image from all others" [Course in General Linguistics 79, 118-19].

The binary opposition between the economic and the cultural is so deeply entrenched that the full implications of the question of Value posed in terms of the "materialist" predication of the subject are difficult to conceptualize. One cannot foresee a teleological moment when these implications are catastrophically productive of a new evaluation. The best one can envisage is the persistent undoing of the opposition, taking into account the fact that, first, the complicity between cultural and economic value-systems is acted out in almost every decision we make; and, secondly, that economic reductionism is, indeed, a very real danger. It is a paradox that capitalist humanism does indeed tacitly make its plans by the "materialist" predication of Value, even as its official ideology offers the discourse of humanism as such; while Marxist cultural studies in the First World cannot ask the question of Value within the "materialist" predication of the subject, since the question would compel one to acknowledge that the text of exploitation might implicate Western cultural studies in the international division of labor. ${ }^{10}$ Let us, if somewhat fancifully, invoke the wordprocessor again. It is an extremely convenient and efficient tool for the production of writing. It certainly allows us to produce a much larger quantity of writing in a much shorter time and makes fiddling with it much easier. The "quality" of writing - the "idealist" question of value - as well as the use-value of manual composition - affectively necessary labor - are rendered irrelevant here. (It is of course not to be denied that the word-processor might itself generate affective use-value.) From within the "idealist" camp, one can even say, in the wake of a trend that runs from Professor A. B. Lord to Father Walter J. Ong, the following: we were not in on the "inception" of writing, and can copiously deplore the harm it did to the orality of the verbal world; we are, however, present at the inception of telecommunication, and, being completely encompassed by the historical ideology of efficiency, we are unable to

\footnotetext{
${ }^{10}$ Hazel Carby, et al., eds., The Empire Strikes Back: Race and Racism in 70s Britain (London: Hutchinson, 1982) is a significant exception. Not only are the authors aware of the connection between racism in Britain and the international division of labor; they are also aware that a study of race relations in Britain cannot pretend to be a general study of the Third World.
} 
reckon with the transformations wrought by the strategic exclusions of the randomness of bricolage operated by programming (see A. B. Lord, The Singer of Tales; Walter J. Ong, Orality and Literacy).

These are not the objections that I emphasize. I draw attention, rather, to the fact that, even as circulation time attains the apparent instantaneity of thought (and more), the continuity of production ensured by that attainment of apparent coincidence must be broken up by capital: its means of doing so is to keep the labor reserves in the comprador countries outside of this instantaneity, thus to make sure that multinational investment does not realize itself fully there through assimilation of the working class into consumerist-humanism. ${ }^{11}$ It is one of the truisms of Capital I that technological inventions open the door to the production of relative rather than absolute surplus-value. [Capital I 643-54. "Absolute surplus-value" is a methodologically irreducible theoretical fiction.] Since the production and realization of relative surplus-value, usually attendant upon technological progress and the socialized growth of consumerism, increase capital expenditure in an indefinite spiral, there is the contradictory drive within capitalism to produce more absolute and less relative surplus-value as part of its crisis management. In terms of this drive, it is in the "interest" of capital to preserve the comprador theater in a state of relatively primitive labor legislation and environmental regulation. Further, since the optimal relationship between fixed and variable capital has been disrupted by the accelerated rate of obsolescence of the former under the rapid progress within telecommunications research and the attendant competition, the comprador theater is also often obliged to accept scrapped and out-of-date machinery from the postindustrialist economies. To state the problem in the philosophical idiom of this essay: as the subject as super-adequation in labor-power seems to negate itself within telecommunication, a negation of the negation is continually produced by the shifting lines of the international division of labor. This is why any critique of the labor theory of value, pointing at the unfeasibility of the theory under post-industrialism, or as a calculus of economic indicators, ignores the dark presence of the Third World. ${ }^{12}$

It is a well-known fact that the worst victims of the recent exacerbation of the international division of labor are women. They are the true surplus army of labor in the current conjuncture. In their case, patriarchal social relations contribute to their production as the new focus of super-exploitation (see June Nash and María Patricia Fernández-Kelly, eds., Women, Men, and the International Division of Labor). As I have suggested above, to consider the place of sexual reproduction and the family within those social relations should show the pure (or free) "materialist" predication of the subject to be gender-exclusive.

The literary academy emphasizes when necessary that the American tradition at its best is one of individual Adamism and the loosening of frontiers. ${ }^{13}$ In terms of political activism within the academy, this free spirit exercises itself at its best by analyzing and calculating predictable strategic effects of specific measures of resistance: boycotting consumer items,

\footnotetext{
1 There is a steadily growing body of work dealing with this phenomenon, a glimpse of which may be found in journals such as NACLA, The Bulletin of Concerned Asian Scholars, and Economic and Political Weekly. A bibliographical starting point would be Kathleen Gough and Hari P. Sharma, eds., Imperialism and Revolution in South Asia (New York: Monthly Review Press, 1973), Part I; Samir Amin, Unequal Development: An Essay on the Social Formations of Peripheral Capitalism, trans. Brian Pearce (New York: Monthly Review Press, 1976); and Cheryl Payer, The Debt Trap: The IMF and the Third World (New York: Monthly Review Press, 1974) and The World Bank: A Critical Analysis (New York: Monthly Review Press, 1982).

${ }^{12}$ See Deborah Fahy Bryceson, "Use Value, The Law of Value and the Analysis of Non-Capitalist Production," Capital \& Class 20(Summer 1983). (I have differences of theoretical detail with Bryceson which are immaterial to my argument here.) My account of the "Third World" here is of the predominant "peripheral capitalist model of development," which works through "an alliance of imperialism with the local exploiting classes" (Samir Amin, The Future of Maoism, trans. Norman Finkelstein [New York: Monthly Review Press, 1982], 9-10).

${ }^{13}$ In spite of necessary qualifications, this argument underlies much of the criticism relating to the U.S. nineteenth century and a certain twentieth century. A general line may be traced from F. O. Matthiessen, American Renaissance: Art and Expression in The Age of Emerson and Whitman (London: Oxford University Press, 1941), through R. W. B. Lewis, The American Adam: Innocence, Tragedy and Tradition in the 19th Century (Chicago: University of Chicago Press, 1955), to, say, Sherman Paul's The Lost America of Love (Baton Rouge: Louisiana State University Press, 1981).
} 
demonstrating against investments in countries with racist domestic politics, uniting against genocidal foreign policy. Considering the role of telecommunication in entrenching the international division of labor and the oppression of women, this free spirit should subject its unbridled passion for subsidizing computerized information retrieval and theoretical production to the same conscientious scrutiny. The "freeing" of the subject as super-adequation in labor-power entails an absence of extra-economic coercion. Because a positivist vision can only recognize the latter, that is to say, domination, within post-industrial cultures like the U.S., telecommunication seems to bring nothing but the promise of infinite liberty for the subject. Economic coercion as exploitation is hidden from sight in "the rest of the world."

These sentiments expressed at a public forum drew from a prominent U.S. leftist the derisive remark: "She will deny the workers their capuccino!" I am not in fact suggesting that literary critics should be denied word-processors. My point is that the question of Value in its "materialist" articulation must be asked as the capuccino-drinking worker and the wordprocessing critic actively forget the actual price-in-exploitation of the machine producing coffee and words. This is certainly not required of every literary critic. But if the literary critic in the U.S. today decides to ask the question of Value only within the frame allowed by an unacknow!edged "nationalist" view of "productivity," she cannot be expected to be taken seriously everywhere. (The real problem is, of course, that she will be taken seriously, and the work of multinational ideology-reproduction will go on.) If my position here is mistaken for an embarrassing economic determinism, the following specification may be made: "There is a short-of and beyond of [economic determinism]. To see to it that the beyond does not become the within is to recognize . . . the need of a communicating pathway (parcours). That pathway has to leave a wake (sillage) in the text. Without that wake or track, abandoned to the simple content of its conclusions, the ultra-transcendental text" - the discourse of textuality in the economic that I have been at pains to explicate and disclose - "will so closely resemble the pre-critical text" - economic determinism - "as to be indistinguishable from it. We must now meditate upon the law of this resemblance" [Derrida, Of Grammatology 61]. I have done no more in this essay than to encourage such a meditation, to suggest that, following Marx, it is possible to put the economic text "under erasure," to see, that is, the unavoidable and pervasive importance of its operation and yet to question it as a concept of the last resort. (Incidentally, this also emphasizes that putting "under erasure" is as much an affirmative as a negative gesture.) In 1985, Walter Benjamin's famous saying, "there has never been a document of culture which was not at one and the same time a document of barbarism" [IIluminations 256] should be a starting rather than a stopping-point for Marxist axiological investigations. A "culturalism" that disavows the economic in its global operations cannot get a grip on the concomitant production of barbarism.

If, on the other hand, the suggestion is made that in the long run, through the multinationals, everyone will have word-processors and capuccino (not to mention guns and butter), the evaluating critic must be prepared to enter the debate between Samir Amin and the late Bill Warren, some of the broad strokes of which I have outlined above [see Warren, Imperialism: Pioneer of Capitalism; Amin, "Expansion or Crisis of Capitalism?]. She must be prepared to admit that the unification churches being projected by the mechanisms of Eurocurrency and "the globalization of markets" (we read it as "global crisis") do not lend much credibility to this uninstructed hope.

Perhaps a word on "The Globalization of Markets," an article by Theodore Levitt, Edward W. Carter Professor of Business Administration and head of the marketing area at the Harvard Business School, is in order here. The piece is exemplary of many of the attitudes I have tried to define. Since Professor Levitt writes from the point of view of big business ("people and nations" in the passage cited below) he is not concerned with the active divisiveness of the international division of labor. Here is his theory of the relationship between money and the division of labor, and his theory of money as a unified concept, reached in turn by way of "experience" as a fetishized concept: "Nobody takes scarcity lying down; everyone wants more. This in part explains division of labor and specialization of production. They enable people and nations to optimize their conditions [a deliberately vague word] through trade. The median [sic] is usually money. Experience teaches that money has three special 
qualities: scarcity, difficulty of acquisition, and transience. People understandably treat it with respect." 14 What I have been arguing is that this primitive notion of money must work complicitously with the contemporary sublation of money where it seems to question the "materialistic" predication of the subject; that the post-modern, in spite of all the cant of modernization, reproduces the "pre-modern" on another scene. In Professor Levitt's article the two views remain in an unresolved and distanced structural parataxis. To quote: "Today money is simply electronic impulses. With the speed of light [so much for Marx's impossible limit for circulation: speed of thought] it moves effortlessly between distant centers (and even lesser places). A change of ten basic points in the price of a bond causes an instant and massive shift of money from London to Tokyo. The system has profound impact on the way companies operate throughout the world" [Levitt 101].

The perspective here is unifocal and generally uncritically read (if read at all) by literary academics. I have been trying to explicate not only the parataxis above, but also the exploitation condensed and monumentalized in a seemingly scientific phrase such as "scaleefficient conditions" below (incidentally, "value" as used here is the unified continuist version that would be consonant with the Marxian definition of value relieved of its historical, ethical, or philosophical charge): "The most endangered companies in the rapidly-evolving world tend to be those that dominate rather small domestic markets with high value-added products for which there are smaller markets elsewhere. With transportation costs" - the only costs specified - "proportionately low, distant competitors will now enter the nowsheltered markets of those companies with goods produced more cheaply under scaleefficient conditions" [Levitt 94]. These "globalizers" also have their human universals: "an ancient motivation - to make one's money go as far as possible. This is universal - not simply a motivation but actually a need" [Levitt 96]. Yet, in an insane parody of the basic paradox of humanistic education, Levitt describes the epistemic violence of the universalizing global market: "The purpose of business is to get and keep a customer. Or, to use Peter Drucker's more refined construction, to create and keep a customer." 15

${ }^{14}$ Theodore Levitt, "The Globalization of Markets," Harvard Business Review 61:3(May-June, 1983):95 $I$ am indebted to Dennis Dworkin for bringing this piece to my attention.

$15 \mathrm{lbid}$., 101. In terms of the ideological interpellation of the subject as consumer, it is worth remarking that the semiotic field here reproduces capitalist as well as patriarchal social relations faithfully: "The Customer" (who is male) does not know what he wants; "Managers [should not be] confidently wedded to a distorted version of the marketing concept according to which you give the customer what he says he wants." But, since the item under discussion here is an automatic washer, the actual target is, of course, "the homemaker" (who is female): "Hoover's media message should have been: This is the machine that you, the homemaker, deserve to have to reduce the repetitive heavy daily household burdens, so that you may have more constructive time to spend with your children and your husband. The promotion should also have targeted the husband to give him, preferably in the presence of his wife, a sense of obligation to provide an automatic washer for her even before he bought an automobile for himself. An aggressively low price, combined with heavy promotion of this kind, would have overcome previously expressed preferences for particular features" [98]. There is something like a relation between this ideological reproduction and reinforcement of the international division of labor in the discourse of patriarchal relations in consumerism, and the reproduction and reinforcement of the international division of labor in the discourse of feminist individualism within socialized capital. Examine, for instance, the following convincingly innocent and unproblematic evaluation of telecommunication in Ms in light of the axiology suggested by considerations of the "materialist" predication of the subject, which the readers of Ms cannot be expected to know since that magazine too is an ideological apparatus within the social arena under consideration. (Incidentally, it is interesting to see how the time-problematic is reversed within a "narrative" context, how the language of narrative-production in telecommunication seeks to recapture a naive "reality." This is a much longer argument which I hope to develop elsewhere.) "Roberta Williams didn't know what she wanted to do with her life until she designed her first microcomputer adventure game three years ago. Today, she is one of the leading designers of home computer games and part owner ... of a $\$ 20$ million business. . . There is something exciting about the continuous motion in arcade games and to use 'real time' (industry lingo for the continuous action that is programmed into the game) within adventure games." Later in the same issue, speaking of "the search business" for women executives, the magazine uses some symptomatic metaphors. "The process is essentially matchmaking. . . . You don't have to have that Dolly [Hello Dolly!] Levi commonsense instinct [read ideology at its strongest] of who-goes-with-whom, and also the diplomacy of Kissinger" [Ms 12:2(August 1983):20, 73]. The relationship between feminist individualism and the military-industrial complex on the one hand, and the problem of anti-sexism within the capitalist enclosure being understood as feminism on the 
This is how economic reductionism operates. The disavowal of the economic is its tacit and legitimizing collaborator. In its verdict on "the multinational mind" as opposed to the globalizing mind is to be heard the managerial version of shock at denying the workers of the First World their capuccino: "the multinational mind, warped into circumspection and timidity by years of stumbles and transnational troubles, now rarely challenges existing overseas practices. More often it considers any departure from inherited domestic routines as mindless, disrespectful, or impossible. It is the mind of a bygone day" [Levitt 101; italics mine].

I should like to construct a narrative here using "The Wiring of Wall Street," an article in the New York Times Sunday magazine for October 23, 1983. (I choose New York Times because the broad spectrum that contains the Sunday supplements of newspapers, Scientific American, Psychology Today, as well as the National Enquirer, constitutes part of an ideological apparatus, through which the consumer becomes knowledgeable, the subject of "cultural" explanation. Could one suggest that organs such as the Harvard Business Review are also part of the apparatus, in that through them the investor-manager receives his "ideology"? As I suggest in note 15, feminist individualist consumerism is being appropriated within the same apparatus.)

After telecommunication, Wall Street seems to have saved by reconciliation (rather than deconstruction) the binary opposition between the immediate self-proximity of voiceconsciousness and the visible efficiency of writing. As Georg Simmel already observes of the stock exchange at the end of the last century, it is the place where the circulation of money can be most speeded up: the "twofold condensation of values into the money form and of monetary transactions into the form of the stock exchange makes it possible for values to be rushed through the greatest number of hands in the shortest possible time" [Simmel 506]. "The start of a solution of the market's major dilemma, the management of time, appeared in 1972 when the New York Stock Exchange, the American Stock Exchange, and their member firms organized the Securities Industries Automation Corporation. . . . Not long ago, the executives kept up with their investments on a monthly or weekly schedule; today, the reporting can be instantaneous because of the computer" ["The Wiring of Wall Street" 47]. It is worth remarking that, even as time is thus being managed on the post-industrial capitalist front, high Marxist theory contests the labor theory of value by bracketing time as a vehicle of change: "No changes in output and . . . no changes in the proportions in which different means of production are used by an industry are considered, so that no question arises as to the variation or constancy of returns" [Sraffa, Production of Commodities v]. If money then circulates at the speed of consciousness by way of the computer, it at the same time accedes to the visible efficiency of writing. "'We had this amorphous, unorganized, mostly invisible market prior to $1971^{\prime}$ says Gordon S. Macklin, president of the [National] Association [of Securities Dealers]" ["Wiring" 73].

This reconciliation of the opposition between consciousness and writing obviously does not "refute" Freud's late proto-deconstructive model of the psyche as the Wunderblok or the mystic writing pad (see Derrida, "Freud and the Scene of Writing," Writing and Difference). If anything, the silicon chip appears to give "a plastic idea" to that pure virtuality, that difference as such which Derrida calls "the work of dead time" [the warning against the formation of a plastic idea is to be found in Freud, The Standard Edition Vol. 4 281: the Derrida passage is in Of Grammatology 68].

But this is not the objection I emphasize here. I point out, rather, that the computer, even as it pushes the frontiers of rationalization, proves unable to achieve bricolage, to produce a program that will use an item for a purpose for which it was not designed. (This is the celebrated problem of programming a computer to build nests with random materials, as a bird does, that exercises Douglas Hofstadter and others.) And it is well-known that radical proto-deconstructive cultural practice instructs us precisely to work through bricolage, to "reconstellate" cultural items by wrenching them out of their assigned function. When Walter

other, is too overdetermined for me to deal with it in more than a footnote. The emergence of an unexamined genitalist axiology of women's suffering and universal sisterhood is also at issue here. What complicates the situation is the overarching presence of hegemonic masculism. 
Benjamin writes: "What we require of the photographer is the ability to give his picture the caption that wrenches it from modish commerce and gives it a revolutionary use-value [Gebrauschswert]," he is implicitly "bricoling" or tinkering with a continuist notion of usevalue (I need not repeat my earlier argument) even as he recommends bricolage as cultural practice. This recommendation can be traced from his earliest theory of allegory as the cathexis (or occupation) of ruins and fragments by the irreducible alterity of time [Benjamin, "The Author as Producer," Reflections: Essays, Aphorisms, Autobiographical Writings 230]. This is to be found in DeLeuze and Guattari's bold notion of originarily unworkable machines. It can be said for Derrida that, by positioning citationality as originary, he has radicalized bricolage as the questioning of all ideologies of adequation and legitimacy. ${ }^{16}$ These positions are now trickling down into a reckoning with the emergent ideological possibilities of the post-modern cultural phenomenon within a post-modern political economy. ${ }^{17}$

It is not even this possibility of a cultural theoretical practice, which sabotages the radically reconciling text of the post-modern stock exchange, that I emphasize within this narrative. My critique can find an allegorical summary in a passage about the old ticker-tape machine. "A holdover from the storied past is the old stock ticker. Fifteen minutes after trading has commenced, the ticker - a bit of technology that dates back to 1867-has already fallen behind the hectic trading by six minutes. Speed it up to match today's trading volume, and it would be a blur" ["Wiring" 47].

We cannot forget that Capital I is "a bit of technology that dates back to 1867," its date of publication. I have attempted to show that the Marxist historical narrative - "the storied past" - is far from a holdover. When it is expanded to accommodate the epistemic violence of imperialism as crisis-management, including its current displacements, it can allow us to read the text of political economy at large. When "speeded up" in this way it does not allow the irreducible rift of the International division of labor to blur. "The Wiring of Wall Street" speaks first of "time management" and next quotes Peter Solomon of Lehman Brothers "offer[ing] an explanation: 'Computers have shown us how to manage risk'" ["Wiring" 47]. The inconvenient and outdated ticker of Marxist theory discloses the excluded word between "time" and "risk" in the management game: crisis.

Let us retrieve the concept-metaphor of the text that we left behind a few pages back. Within this narrative replay of my argument in the previous pages it may be pointed out that, whereas Solomon Brothers, thanks to computers, "earned about $\$ 2$ million for . . 15 minutes of work," the entire economic text would not be what it is it could not write itself as a palimpsest upon another text where a woman in Sri Lanka has to work 2,287 minutes to buy a t-shirt. The "post-modern" and "pre-modern" are inscribed together. It should also be remarked that Simmel argued nearly a hundred years ago that a developed money-form naturally promotes "the individual": "if freedom means only obeying one's own laws, then the distance between property and its owner that is made possible by the money form of returns provides a hitherto unheard-of freedom" [Simmel 334]. The best beneficiary of this "post-modernization" of Wall Street is, predictably, the individual small investor in the United States. And the apparently history-transcendent "individual subject" who will "have to hold to the truth of postmodernism . . . and have as its vocation the invention and projection of a global cognitive mapping" Jameson, "Postmodernism, or the Cultural Logic of Late Capitalism" 92] will be, as long as no attempt is made to specify the post-modern spacespecific subject-production, no other than a version of this unpromising individual.

It is within this framework of crisis-management and regulation, then, that I would propose to pursue the evaluation of the pervasive and tacit gesture that accepts the history of style-formations in Western European canonical literature as the evaluation of style as such. I am not recommending varieties of reactive nostalgia such as an unexamined adulation of working class culture, an ostentatious rejection of elitist standards, a devotion to all non-

\footnotetext{
$16 /$ am grateful to Todd Snyder for suggesting this line of thought to me.

${ }^{17} \mathrm{~A}$ representative essay would be Fredric Jameson, "Postmodernism and Consumer Society," Hal Foster, ed., The Anti-Aesthetic. As is demonstrated in the revised version of this essay, to be found in New Left Review as "Postmodernism, or the Cultural Logic of Late Capitalism," Jameson is ambivalent about these possibilities.
} 
Judaeo-Christian mythologies, or the timid evocation of "poetry being written in Nicaragua." In fact, the version of historical narrative I am sketching here can be expanded to show that, in such nostalgic evaluative norms as the list above, the history of the epistemic violence of imperialism as crisis-management can still operate. Regular periodization should rather be seen in its role within the historical normalization required by the world-system of political economy, engaged in the production and realization of Value, the "post-modern" its latest symptom. Such evaluations would accommodate the "materialist" articulation of Value within what I described earlier as the practical position of Value in our discipline in the narrow sense, underlining the role of exploitation in understanding domination. ${ }^{18}$

In "Marx's (not Ricardo's) 'Transformation Problem,'" Richard A. Wolff, Bruce Brothers, and Antonino Collari suggest that when "Marx ... considers a social object in which the processes of circulation constitute effective preconditions for the process of production, . . .

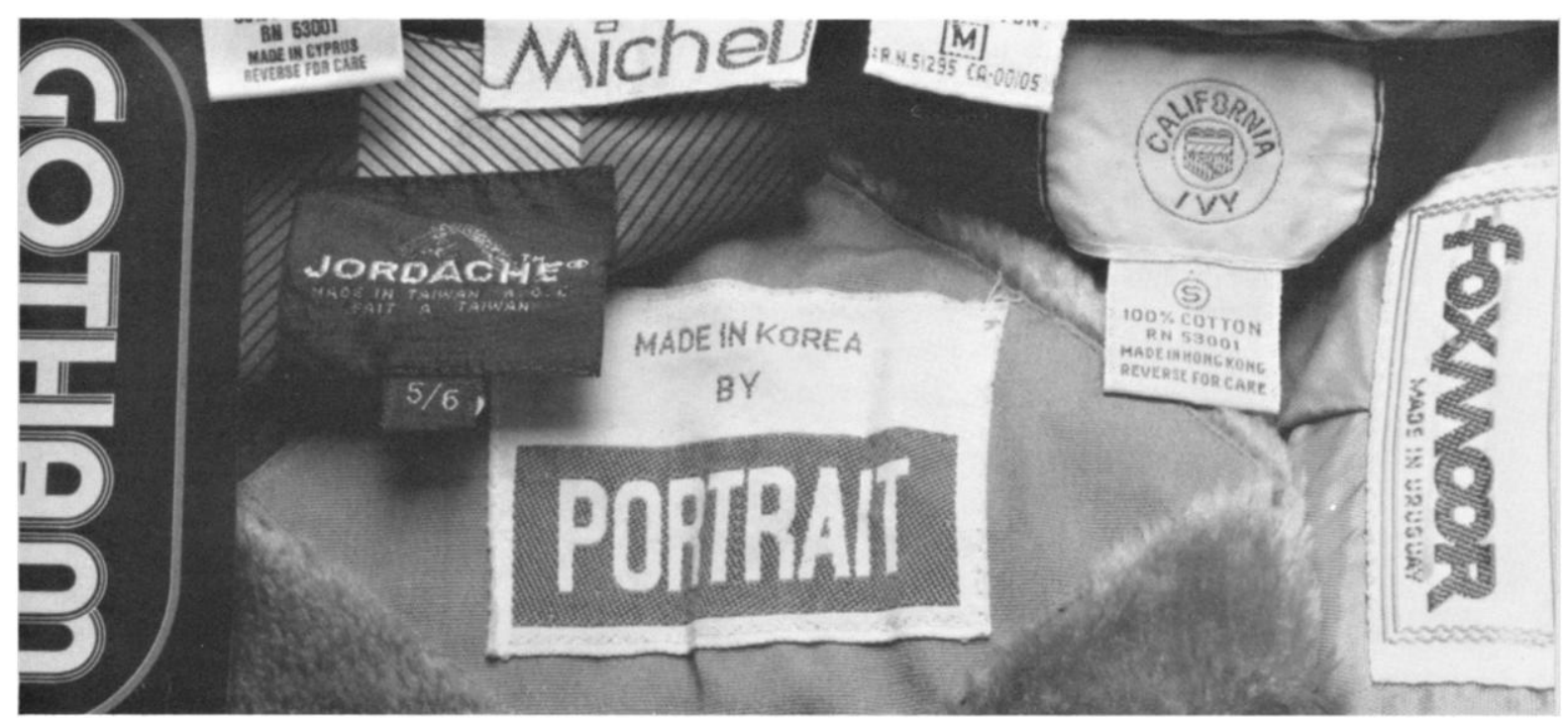

the relevant magnitude must be the price of production of the consumed means of production and not the abstract labor time physically embodied in them" [Wolff et al., "Marx's 'Transformation Problem,'" 574]. I have so far been arguing, among other things, that to set the labor theory of value aside is to forget the textual and axiological implications of a materialist predication of the subject. The passage I quote, however, seems to be an appropriate description of the perspectival move which provisionally must set that theory aside. As a result of this move, "the equivalence of exchange must be constructed out of the processes specific to competitive capitalism which tend to establish a proportional distribution of unpaid labor time in the form of an average rate of profit on total capital, no longer assumed as in volume 1" ["Marx's 'Transformation Problem'" 572; italics mine, and I have conflated three

\footnotetext{
${ }^{18}$ The Marx that is useful here is not the philosopher of history, but rather the theoretician of crisis. It is in the sketched theory of crisis that Marx most anticipates the international division of labor, least imposing the normative narrative of modes of production in the world outside Western Europe. Concise accounts of crisis theory, and crisis theory and contemporary imperialism, are to be found in Robert $I$. Rhodes, ed., Imperialism and Underdevelopment: A Reader (New York: Monthly Review Press, 1970). A systematic development of Marx's theory of production, distribution, and circulation into the regulation of crises is to be found in Michel Aglietta, A Theory of Capitalist Regulation. Peter F. Bell and Harry Cleaver give an account of the development of Marx's own theory of crisis in "Marx's Theory as a Theory of Class Struggle," Research in Political Economy 5(1982).
} 
sentences]. Thus the authors situate the specific arena of the labor theory of value but go on to suggest that, since "Marx's focus [was] on class relations as his object of discourse ... simultaneously, however, the concept of value remains crucial to the quantification of prices of production. Price on production, as an absolute magnitude of labor time, can be conceived only as a specific deviation from value" ["Marx's 'Transformation Problem'" 575; italics mine].

I have not touched the topic of the value-price relationship in these pages. Further, I have questioned the mechanics of limiting the definition of value to the physical embodiment of abstract labor time. I would in fact argue that the premises of Capital I are themselves dependent upon a gesture of reduction that may be called a construction [Capital I 135]. Generalizing from Wolff's and his co-authors' position, I would find that Marx's focus on class (mode of production) must be made to accommodate his reach on crisis (world system). Yet Wolff and his co-authors' perspectival situation of the labor theory of value and concurrent definition of price of production as deviation or differential seem to us admirably just. Within the discipline of economics, which must keep any textualized notion of use-value out, it seems crucial to suggest that "Marx . . . affirms the interdependence of value and value form ([understood as] price of production), an interdependence which cannot be expressed by treating the relation between the two concepts as merely a functional relation between dependent and independent variables." 19 As I move more conclusively into the enclosure of my own disciplinary discourse, perhaps it might not be inappropriate to suggest that this essay does no more than point at the confused ideological space of some varieties of such an interdependence.

I will now appropriate yet another item on the threshold of this essay: the Derridian concept of "interest" as in "scrupulous declaration of interest." Derrida's own understanding of surplus-value as capital-appreciation or interest is, as I have suggested above, restricted. I simply wrest it back from that "false" metaphor and "literalize" it. ${ }^{20}$ If and when we ask and answer the question of value, there seems to be no alternative to declaring one's "interest" in the text of the production of Value.

I offer this formula because the problem of "how to relate a critique of 'foundationalism,' which like its object is interminable and may always go astray, to a critique of ideology that allows for at least provisional endings and ends in research and 'political' practice" remains with us [Dominick La Capra, Lecture given at Wesleyan University, 1984]. The early Derrida assured us that "deconstruction falls a prey to its own critique" and went largely unheeded [Of Grammatology 24]. The later Derrida, miming this precaution interminably, has been written off as, at best, a formal experimentalist or, at worst, uninteresting and repetitive. It should be clear from the last few pages that I can endorse Jean-François Lyotard's benevolent

\footnotetext{
19"Marx's Transformation Problem," p. 576. This, incidentally, also reveals the mistake of the layperson who "refutes" the labor theory of value because "you cannot deduce prices from it." Marx's theory is one where politics, economics, and ideology are relatively autonomous in the determination of class relations in the broadest sense. The point, therefore, is not to reduce value to a calculus of price, especially within models of general equilibrium. Wolff, et al. do produce equations that take this into account. They are, however, aware that the more important issue is that the practical moment in Marx questions abstract economic rigor; even as I argue in the body of this essay that the axiological moment in Marx questions mere philosophical justice.

${ }^{20}$ The most powerful development of this conception is the mysterious Spurs: Nietzsche's Styles, trans. Barbara Harlow (Chicago: University of Chicago Press, 1978). Part of the mystery lies, I think, in that Derrida is here trying to make "woman his subject" (his "interest"?) and hint enigmatically at "affirmative deconstruction." As I will soon explain, my notion of interest must take the risk of being related to the deliberative consciousness. Over a year after the writing of this essay, at the point of implementing the final editorial suggestions, I begin to realize how astutely Paul de Man had predicted this move from "false" metaphor to "literalization" in the field of political practice. It would take a careful elaboration of de Man's entire complex argument in Allegories of Reading to establish the parallel between my move here and grammar and "figure" in the following definition of textuality: "We call text any entity that can be considered from . . . a double perspective: as a generative, open-ended, non-referential grammatic system and as a figural system closed off by a transcendental system that subverts the grammatical code to which the text owes its existence" [Paul de Man, Allegories of Reading 270; italics mine]. Suffice it here to consolidate the parallel by pointing out that, towards the bottom of the same page, de Man aphoristically describes the necessity of this subversion, this closing off, in the following way: ". . and if a text does not act, it cannot state what it knows" (italics mine).
} 
"paganism" as an axiological model as little as I can Jürgen Habermas's Europocentric rationalism. UJean-François Lyotard, Instructions païennes; Rudiments païens with Jean-Loup Thébaud, Au juste. Jürgen Habermas, Communication and the Evolution of Society.] One of the more interesting solutions offered is Dominick La Capra's "historiography as transference." Yet there, too, there are certain desires to appropriate the workings of the unconscious of which we should beware. For "repetition-displacement of the past into the present" (La Capra's version of transferential historiography) may be too continuist and harmless a version of the transactions in transference. And it might not be enough simply to say that "it is a useful critical fiction to believe that the texts or phenomena to be interpreted may answer back and even be convincing enough to lead one to change one's mind" [La Capra, History and Criticism 73]. Given Lacan's elaborate unfolding of the relationship between transference and the ethical moment, I can do no better here than to reiterate an earlier doubt, expressed not in terms of historiography but rather of literary criticism:

Nor will the difference between text and person be conveniently effaced by refusing to talk about the psyche, by talking about the text as part of a self-propagating mechanism. The disjunctive, discontinuous metaphor of the subject, carrying and being carried by its burden of desire, does systematically misguide and constitute the machine of text, carrying and being carried by its burden of "figuration." One cannot escape it by dismissing the former as the residue of a productive cut, and valorizing the latter as the only possible concern of a "philosophical" literary criticism. This opposition too, between subject "metaphor" and text "metaphor," needs to be indefinitely deconstructed rather than hierarchized. [Spivak, "The Letter as Cutting Edge," Literature and Psychoanalysis: Reading Otherwise 225]

The formula - "scrupulous declaration of interest in the text of the production of Value" - that I offer comes out of the most problematic effect of the sovereign subject, the so-called deliberative consciousness. Thus, there is no guarantee in deconstruction for freezing this imperative into a coercive theoretical universal, though it is of course subject to all the constraints of ethico-logical grounding. The encroachment of the fictive (related, of course, to the textual) upon this operation cannot be appreciated without passing through the seemingly deliberative, which, even in the most self-conscious transferential situation, can, at any rate, only be resisted rather than fully avoided.

In closing, I will invoke the very threshold, the second paragraph of this essay, where I write: "The 'idealist' and the 'materialist' are both exclusive predications." All predications are exclusive and thus operate on the metonymic principle of a part standing for the putative whole: "As soon as one retains only a predicate of the circle (for example, return to the point of departure, closing off the circuit), its signification is put into the position of a trope, of metonymy if not metaphor" [Derrida, "White Mythology" 264]. In this sense, the "idealist" and the "materialist" predications of the subject are metonyms of the subject. Writing of the constitution of the subject as such, Lacan writes: "The double-triggered mechanism of metaphor is the very mechanism by which the symptom ... is determined. And the enigmas that desire seems to pose for a 'natural philosophy' . . . amount to no other derangement of instinct than that of . . metonymy" ["The Agency of the Letter in the Unconscious" Ecrits 166-67]. In so far as the two predications are concepts of the subject, they are unacknowledged metaphoric substitute-presentations of the subject. Between metaphor and metonymy, symptom and desire, the political subject distances itself from the analyst-intransference by declaring an "interest" by way of a "wild" rather than theoretically grounded practice. Lest I seem, once again, to be operating on an uncomfortable level of abstraction, let me choose a most non-esoteric source. Here is the McGraw-Hill Dictionary of Modern Economics on the encroachment of the fictive upon the deliberative in the operation of the economic text:

Originally the Dow-Jones averages represented the average (arithmetical mean) price of a share of stock in the group. As stocks split, the substitution of issues in the averages, and other factors occurred, however, a formula was devised to compensate for these changes. Although the Dow-Jones averages no longer represent the 
actual average prices of these stocks in the groups, they still represent the levels and changes in the stock-prices reasonably well. [178]

I say above that "the full implications of the question of Value posed within the 'materialist' predication of the subject cannot yet be realized." I must now admit what many Marxist theoreticians admit today: that in any theoretical formulation, the horizon of full realization must be indefinitely and irreducibly postponed. On that horizon it is not utopia that may be glimpsed [see Jameson, The Political Unconscious: Narrative As A Socially Symbolic Act 103f]. For utopias are historical attempts at topographic descriptions that must become dissimulative if attempts are made to represent them adequately in actual social practice. The complicity between idealisms and materialisms in the production of theory is better acknowledged, even as one distances oneself from idealism, if one designates this open end by the name of the "apocalyptic tone." 21 This tone announces the pluralized apocalypse of the practical moment, in our particular case the set or ensemble of ideologycritical, aesthetic-troping, economically-aware performative or operational value-judgment. My careful language here should make clear that the practical moment is not a "fulfillment." In the pluralized apocalypse, the body does not rise. There is no particular need to see this as the thematics of castration. Why not affirm as its concept-metaphor the performative and operational evaluation of the repeated moves of the body's survival and comfort, historically named woman's work or assigned to domestic labor when it is minimally organized? Why appropriate the irreducible non-fit between theory and practice (here in the grounding and making of Value judgments) into Oedipus's hobble?

I offer, then, no particular apology for this deliberate attempt to show the difference between pre-critical economism and the role of the economic text in the determination of Value; and, further, to plot some of the "interests" in its foreclosure.

\section{WORKS CITED}

Althusser, Louis. For Marx. Trans. Ben Brewster. London: New Left Books, 1977. . Lenin and Philosophy. Trans. Ben Brewster. New York: Monthly Review Press, 1971.

Benjamin, Walter. "Theses on the Philosophy of History." Illuminations. Trans. Harry Zohn.

Ed. Hannah Arendt. New York: Schocken, 1969, 253-64. . "The Author as Producer." Reflections: Essays, Aphorisms, Autobiographical Writings.

Trans. Edmund Jephcott. Ed. Peter Demetz. New York: Harvest, 1978.

Bowles, Samuel, et al., eds. Beyond the Waste Land: A Democratic Alternative to Economic Decline. Garden City: Anchor, 1983.

Deleuze, Gilles and Félix Guattari. Anti-Oedipus: Capitalism and Schizophrenia. Trans.

Robert Hurley, et al. New York: Viking, 1977. Mille plateaux. Paris: Minuit, 1980.

de Man, Paul. Allegories of Reading. New Haven: Yale University Press, 1979.

Derrida, Jacques. "The Law of Genre." Glyph 7(1980):202-29. Of Grammatology. Trans. Gayatri Chakravorty Spivak. Baltimore: Johns Hopkins

University Press, 1976

Positions. Trans. Alan Bass. Chicago: University of Chicago Press, 1981.

"White Mythology: Metaphor in the Text of Philosophy." Margins of Philosophy.

Trans. Alan Bass. Chicago: University of Chicago Press, 1982, 209-71.

Freud, Sigmund. The Standard Edition of the Complete Psychological Works. Volume IV.

Trans. James Strachey, et al. London: Hogarth Press, 1961.

Goux, Jean-Joseph. “Numismatiques I." Tel Quel 35(Autumn 1968):64-89.

. "Numismatiques II." Tel Quel 36(Winter 1969):54-74.

${ }_{21}$ "On An Apocalyptic Tone Recently Adopted in Philosophy," trans. John P. Leavey, Ir., Semeia 23(1982). I believe it is possible to read in this obscure text a practical politics of the open end. I hope to write in detail of it in my forthcoming book on Derrida. I will content myself with quoting a relatively less aphoristic sentence: "To raise or set the tone higher . . . is to . . make the inner voice delirious, the inner voice that is the voice of the other in us" [71]. 
Habermas, Jürgen. Communication and the Evolution of Society. Trans. Thomas McCarthy. Boston: Beacon Press, 1979.

Jameson, Fredric. The Political Unconscious: Narrative As A Socially Symbolic Act. Ithaca: Cornell University Press, 1982.

. "Postmodernism, or The Cultural Logic of Late Capitalism." New Left Review

146(July-August 1984):53-92.

. "Postmodernism and Consumer Society." The Anti-Aesthetic: Essays on Postmodern

Culture. Ed. Hal Foster. Port Townsend, Washington: Bay Press, 1983, 111-25.

Lacan, Jacques. "The Agency of the Letter in the Unconscious or Reason since Freud." Ecrits.

Trans. Alan Sheridan. New York: Norton, 1977, 146-78.

. "The Signification of The Phallus." Ecrits, 281-91.

La Capra, Dominick. History and Criticism. Ithaca: Cornell University Press, 1985.

Lord, A. B. The Singer of Tales. Cambridge: Harvard University Press, 1960.

Lyotard, Jean-François. Instructions paiennes. Paris: Galilée, 1977.

Rudiments paiens. Paris: U.G.E., 1977.

Lyotard, Jean-François and Jean-Loup Thébaud. Au juste. Paris: Christian Bourgeois, 1979.

Levitt, Theodore. "The Globalization of Markets." Harvard Business Review 61:3(May-June 1983):92-102.

Marx, Karl. Capital. Vol. I. Trans. Ben Fowkes. New York: Vintage, 1976. Capital. Vol. III. Trans. David Fernbach. New York: Vintage, 1981.

A Contribution to the Critique of Political Economy. Trans. S. W. Ryazanskaya. New York: International Publishers, 1970.

Grundrisse: Foundations of the Critique of Political Economy. Trans. Martin Nicolaus. New York: Vintage, 1973.

. "Economic and Philosophic Manuscripts of 1844." Early Writings. Trans. Rodney Livingstone and Gregor Benton. Ed. Quintin Hoare. New York: Vintage, 1975, 279-400.

McGraw-Hill Dictionary of Modern Economics: A Handbook of Terms \& Associations. New York: McGraw-Hill, 1973.

Nash, June and María Patricia Fernández Kelly, eds. Women, Men and the International Division of Labor. Albany: State University of New York Press, 1983.

Nietzsche, Friedrich. "On the Genealogy of Morals" and "Ecce Homo." Trans. Walter Kaufman and R. J. Hollingdale. New York: Vintage, 1967.

Ong, Walter J. Orality and Literacy. London: Methuen, 1982.

Saussure, Ferdinand de. Course in Ceneral Linguistics. Trans. Wade Baskin. Ed. Charles Bally and Albert Secehaye in collaboration with Albert Riedlinger. New York: McGrawHill, 1966.

Shell, Marc. Money, Language, and Thought: Literary and Philosophical Economies From the Medieval to the Modern Era. Berkeley: University of California Press, 1982.

Simmel, Georg. Philosophy of Money. Trans. Tom Bottomore and David Frisby. London: Routledge and Kegan Paul, 1978.

Smith, Desmond. "The Wiring of Wall Street." New York Times Sunday Magazine. Oct. 23, 1983, 44.

Spivak, Gayatri Chakravorty. "The Letter as Cutting Edge." Literature and Psychoanalysis. Baltimore: Johns Hopkins University Press, 1982, 208-26.

"Displacement and the Discourse of Woman." Displacement: Derrida and After.

Ed. Mark Krupnick. Bloomington: University of Indiana Press, 1983, 169-95.

Sraffa, Piero. Production of Commodities By Means of Commodities. Cambridge: Cambridge University Press, 1960.

Wolff, Richard D., et al. "Marx's (not Ricardo's) 'Transformation Problem': A Radical Conceptualization." History of Political Economy 14:4(1982). 